П. С.Зеленковский ${ }^{1}$ И. И. Подлипский ${ }^{1}$ В.Р.Хохряков ${ }^{2}$

ПРОБЛЕМЫ РЕГУЛИРОВАНИЯ ДЕЯТЕЛЬНОСТИ

ХОЗЯЙСТВУЮЩИХ СУБЪЕКТОВ

ПРИ РАЗРАБОТКЕ МЕСТОРОЖДЕНИЙ ПОЛЕЗНЫХ ИСКОПАЕМЫХ В ГРАНИЦАХ ОСОБО ОХРАНЯЕМЫХ ПРИРОДНЫХ ТЕРРИТОРИЙ

${ }^{1}$ Санкт-Петербургский государственный университет,
Российская Федерация, 199034, Санкт-Петербург, Университетская наб., 7-9
${ }^{2}$ Национальный парк «Смоленское Поозерье»,
Российская Федерация, 216270, Смоленская обл., Демидовский р-н, пос. Пржевальское, ул. Гуревича, 19

Рассмотрены особенности природопользования в пределах особо охраняемых природных территорий. На примере сложного природно-техногенного комплекса района озера Баскунчак показаны проблемы, возникающие при нерациональном использовании природных ресурсов, и предложены пути их решения. Библиогр. 26 назв. Ил. 1.

Ключевые слова: особо охраняемые природные территории, естественные ресурсы соленакопления, эколого-геологический заказник.

P. S. Zelenkovskii ${ }^{1}$, I. I. Podlipsky ${ }^{1}$, V. R. Khokhryakov ${ }^{2}$

\title{
PROBLEMS OF REGULATION OF ACTIVITY OF ECONOMIC ENTITIES IN THE DEVELOPMENT OF MINERAL DEPOSITS WITHIN THE BOUNDARIES OF PROTECTED AREAS
}

${ }^{1}$ Saint Petersburg State University, 7-9, Universitetskaya nab., St. Petersburg, 199034, Russian Federation

${ }^{2}$ National Park Smolensk Lakeland, 19, ul. Gurevicha, pos. Prjevalskoe, Demidovskiy raion, Smolenskaya obl., 216270 region, Russian Federation

The article describes the features of environmental management within protected areas. The problems of the interaction of an economic entity and protected areas. For example, a complex of natural and technogenic complex Baskunchak Lake area shows problems associated with unsustainable use of natural resources and ways of their solution. Refs 26. Fig. 1.

Keywords: protected areas, natural resources of salt accumulation, ecological and geological reserve.

\section{Введение}

В мире сегодня существует огромное количество различных типов особо охраняемых природных территорий (ООПТ) - около 1500, а в России - семь основных разновидностей.

Правовое регулирование деятельности российских ООПТ обеспечивается на основании Ф3 [1] и региональных или федеральных подзаконных актов. Причем точность формулировок в документах является гарантом эффективности работы ООПТ.

Вопрос о том, что же является главной ценностью заповедной территории, широко освещен в научной и методической литературе, что неудивительно, поскольку его решение позволяет создать благоприятные условия для сохранения природных компонентов. По мнению некоторых авторов, главной ценностью ООПТ являются системы самоподдержания биосферы, природные «мощности», регулирующие состояние окружающей среды [2].

(c) Санкт-Петербургский государственный университет, 2016 
Другие ученые обращают внимание, что в природных системах можно выделить продукционную и информационную составляющие. Причем под информационной составляющей подразумевается инструментарий экосистемы, то количество элементов, которое позволяет сохранять гомеостаз системы $[2,3]$.

\section{Использование природных ресурсов ООПТ}

Охрана компонентов окружающей среды в условиях ООПТ не исключает различного характера использования их ресурсов. Это - организация и проведение научных исследований, экологическое просвещение и развитие познавательного туризма. Кроме того, на территориях государственных природных заказников, где проживают малочисленные этнические общности, допускается использование природных ресурсов в формах, обеспечивающих защиту исконной среды их обитания и сохранение традиционного образа их жизни [1, ст. 24], а также «допускается размещение объектов капитального строительства и связанных с ними объектов инфраструктуры... деятельность, которая направлена на обеспечение функционирования... и жизнедеятельности граждан... развития познавательного туризма, физической культуры и спорта» [1, ст. 9 и 10].

Рекреационный ресурс достаточно часто используется на ООПТ различных типов. Например, «Карадагский природный заповедник» (Крым) помимо научных успешно решает задачи экологического просвещения и развития познавательного туризма. По территории и акватории ООПТ проложены четыре экскурсионных маршрута, назначение которых - знакомство с природой заповедника. Маршруты доступны для посетителей в течение всего года, экскурсии проводятся организованными группами в сопровождении сотрудника заповедника. Подобные мероприятия достаточно популярны, особенно в тех ООПТ, которые расположены вблизи туристических центров. Спектр туристических услуг ООПТ различных типов достаточно широк. Помимо экологических троп, это может быть сельский (деревенский, фермерский) туризм, спортивный и экстремальный туризм, этнографический туризм и т.д.

Условия соблюдения режима охраны в этих случаях выполняются за счет жесткой регламентации маршрута следования туристических групп, количества посетителей, режима посещения.

В ООПТ допускается проживание населения, которое ведет свою хозяйственную деятельность традиционным образом. Регламент ООПТ позволяет создавать на указанных территориях отдельные кластеры различного назначения, в том числе «включая зоны охраны историко-культурных комплексов и объектов...» [1, ст. 21]. На территориях, где проживают малочисленные этнические общности, допускается использование природных ресурсов в формах, обеспечивающих защиту исконной среды обитания малочисленных народов и сохранение традиционного образа их жизни [1, ст. 24].

Отметим, что в данном случае применение термина закона «малочисленные этнические общности» достаточно дискуссионно. Понятна цель снятия запретов на традиционное природопользование - сохранение уникальных механизмов взаимодействия человека и природы, выраженных в укладе жизни малочисленных этнических групп, сохранение которых в отрыве от природы невозможно. 
По большому счету традиционный уклад жизни является результатом своеобразного симбиоза человека и биосферы в локальной точке, сложившегося за многие сотни лет. Говорить о девственной природе в таком случае уже невозможно, поскольку человек уже стал частью этой системы, которая находится в гомеостазе. Извлекая один из элементов из системы (человека), можно нарушить всю природно-антропогенную систему и будет утерян и уникальный этно-культурный кластер, и изменится природная составляющая. Поэтому охранный статус распространяется не только на природный компонент, но и на механизмы взаимодействия человека и природы, уже ставшие частью новой природно-антропогенной системы.

По нашему мнению, использовать природные ресурсы лишь в интересах малочисленных этнических групп тоже неверно. Территория центральной и северной части России, «русского Севера», Сибири в тех районах, что не были затронуты промышленностью, и населенная представителями титульной нации уже сотни лет, может рассматриваться как зона экосистем изначально нарушенных природопользованием, но ныне находящаяся в состоянии симбиоза с человеком. Рыбная ловля, сбор грибов, ягод, трав, бортничество, охота - являются традиционными видами использования ресурсов. В таком случае также возникает вопрос регламентации такой деятельности и четкого контроля.

На территории ООПТ достаточно остро стоят проблемы регулирования хозяйственной деятельности, и в частности, обращения с отходами. В России, в целом, ежегодно образуется около 130-150 млн. м³ твердых бытовых отходов (ТБО), из них порядка 3 \% подвергается промышленной переработке, остальные вывозятся на свалки и полигоны-захоронения с отчуждением земель в пригородной зоне и загрязнением окружающей среды. Так, существует множество примеров, когда вновь созданные ООПТ наследовали полигоны ТБО, существовавшие на данной территории ранее. Перестроить всю систему обращения с ТБО для территории достаточно сложно, поэтому часто предприятия продолжают существовать уже в рамках ООПТ [4-7].

Негативное воздействие полигона ТБО на окружающую природную среду отмечалось многими авторами [8-10]. Такие примеры не единичны. Однако механизмов взаимодействия полигона ТБО и ООПТ до сих пор предложено не было.

Сложнее обстоит вопрос промышленного природопользования в пределах ООПТ. Разведка и добыча полезных ископаемых является важнейшей составляющей экономики России. В настоящее время во взаимодействии горнодобывающих компаний и особо охраняемых территорий нередко возникают неразрешимые противоречия, основанные на комплексе недоработок и архаизмов в двух параллельно развивающихся отраслях, которые вместе приводят к негативным последствиям как для горнодобывающей отрасли, так и, пожалуй, в большей степени, особо охраняемых природных территорий.

Заказник - это единственная форма организации ООПТ, на территории которой нет абсолютного запрета на проведение горных работ. Однако часто отсутствие проработанного механизма защиты природных комплексов и несогласованность добычной и природоохранной методологии являются причиной нерационального использования ресурсов и негативного воздействия на окружающую среду.

Научное обоснование эксплуатации ресурсов таких природных объектов на основе учета восстановительного потенциала экосистемы в настоящее время невыполнимо, поскольку невозможна сама эксплуатация как деятельность, про- 
тиворечащая целям создания ООПТ. С другой стороны, в современной литературе, достаточно часто встречаются мнения, что природоохранное законодательство Российской Федерации фактически идет по запретительному пути всех видов хозяйственной и иной деятельности в пределах ООПТ, которая теоретически может нанести вред данным территориям и не соответствует целям их образования [10] или что в последние годы наблюдается опасная тенденция к постоянному увеличению числа ООПТ в стране и расширению границ уже созданных территорий $[11,12]$. Такая позиция в целом не лишена логики и обоснована рядом факторов, сложившихся исторически. Примером может служить ситуация на Кумжинском месторождении, северная часть которого находится на территории государственного природного заповедника федерального значения «Ненецкий». На участке расположены законсервированные и ликвидированные после аварии 1980 г. скважины, находившиеся в опасном для окружающей среды состоянии. Работы по ликвидации негативных последствий на самом деле могут включать в себя добычу газа, так как стоит острая необходимость компенсировать высокое давление в аварийный скважинах, что можно наиболее эффективно сделать путем добычи газа, но что противоречит действующему правовому статусу заповедника [10].

Примеры ситуаций, когда в пределах одной природой системы сталкиваются интересы горного предприятия и ООПТ, есть и за рубежом. Так, на территории национального парка «Какаду» (Австралия) находятся несколько разведанных месторождений урана и золота. Причем совокупные запасы месторождений урана оцениваются 25-30\% от мировых запасов [13]. Освоение данной территории началось как раз с разведки месторождений урана в обустройства инфраструктуры по его добыче и переработке. Образованный два десятилетия спустя национальный парк «Какаду» окружил территорию горного кластера, что привело к обострению ряда проблем, связанных с эксплуатацией существующих карьеров и разведкой новых месторождений. Гигантские запасы стратегического сырья - урана, а также золота, которые, безусловно, крайне необходимы для развития любого государства, интересы аборигенных племен, которые также существуют на данной территории, и проблема сохранения природных богатств национального парка - все это стало элементами неразрешимой до сих пор задачи.

Очевидно, что эксплуатация месторождений, включенных в состав ООПТ, это вопрос острый и неоднозначный. Тем более подход к этой проблеме с позиции разрешения добычи полезных ископаемых и снятия любых запретов не согласуется с общемировой тенденцией увеличения территорий ООПТ (почти в 2 раза за последние 10 лет [14]).

Оценки ресурсов сложных природно-техногенных комплексов, к которым относятся и месторождения, и особо охраняемые природные территории, являются предельно пристрастными и диаметрально противоположными в зависимости от того, как рассматривать природный объект. Противоречия становятся практически неразрешимыми, если добыча полезных ископаемых планируется в непосредственной близости или на территории ООПТ.

Рассмотрим пример сложного природного-техногенного комплекса, где переплелись интересы двух месторождений и ООПТ (район озера Баскунчак, Ахтубинский р-н, Астраханская обл.), а также обнаружились проблемы, связанные 
с управлением такой сложной системой. Соляное озеро Баскунчак является уникальным геологическим объектом мирового масштаба и представляет собой часть сложной природной системы [15-17]. Природный объект сформировался в течение четвертичного периода в результате поднятия четырех соляных куполов. Соляная тектоника полностью определяет облик района. Например, карстовые процессы в породах соляных куполов, которые были характерны для территории объекта на начальных стадиях развития, обеспечили район озера огромным, по сравнению с прилегающими степями, количеством мест обитания редких живых организмов (провалы, воронки, пещеры).

Внешний вид оз. Баскунчак отличается от озера в привычном понимании

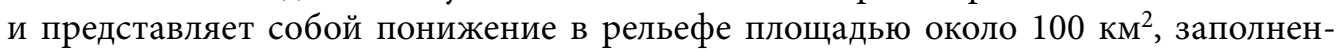
ное рапой и соляными озерными отложениями. Летом, когда уровень рапы падает ниже соляных отложений, озеро представляет собой соляной пласт, на поверхности которого располагаются все коммуникации соляного прииска. Зимою - это водоем глубиной не более $1 \mathrm{~m}$, заполненный рапой.

Месторождение характеризуется уникальным механизмом восстановления запасов солей, которое обеспечивается за счет непрерывного роста соляных куполов и их выщелачивания подземными и поверхностными водами. По нашим оценкам, в процессе эвапоритовой седиментации происходит накопление экологически чистых пищевых солей в количестве порядка 1,5 млн т в год. Этот природный ресурс по аналогии с естественными ресурсами подземных вод предложено называть естественными ресурсами соленакопления $[17,18]$.

Соляные купола, рост которых продолжается и сегодня, определяют особый гидрохимический режим всей территории, особенности движения подземных и поверхностных вод. Именно подземные воды обеспечивают состояние динамического гомеостаза всей системы в границах водосборной площади. С другой стороны, антропогенное воздействие на эту часть системы может в кратчайшие сроки привести к ее дисбалансу и разрушению.

В связи с этим остро стоит вопрос согласованного хозяйствования на всей территории объекта, что становится проблематичным в условиях наличия большого количества природопользователей. Действительно, район оз. Баскунчак также богат и другими природными ресурсами, кроме озерных солей: бальнеологическими илами озера, строительными материалами (гипс соляных куполов). В пределах водосборной площади находятся:

- соляной промысел ОАО «Бассоль» (акватория озера, территория БогдоБаскунчакского заказника);

- гипсовый карьер $3 \mathrm{AO}$ «Кнауф Гипс Баскунчак» (горный отвод предприятия расположен в границах экосистемы);

- поселки Нижний Баскунчак, Средний Баскунчак, их инфраструктура (территория в границах экосистемы, но вне ООПТ);

- месторождение бальнеологических солей (территория заказника);

- Богдо-Баскунчакский заповедник федерального уровня;

- Богдо-Баскунчакский заказник регионального уровня.

Для установления режима рационального природопользования и сохранения уникального природного объекта необходима согласованная деятельность указанных предприятий и образований на основе научно обоснованных нормативов, 
отражающих закономерности развития и существования природно-техногенной системы озера.

Как показал опыт, без введения научно обоснованных нормативов воздействия эксплуатация ресурсов оз. Баскунчак приводит к катастрофическим последствиям - активизации карстовых процессов, ухудшении, вплоть до потери качества соляных ресурсов. Негативные последствия такой бесконтрольной отработки солей во второй половине XX в. проявились по всей территории природной системы - и в акватории (засорение пласта, соляной карст, снижение качества ресурса), и в водосборной площади (карстовые провалы), где расположены другие хозяйствующие субъекты [16].

В пределах водосборной площади озера находится второе горное предприятие - 3АО «Кнауф Гипс Баскунчак», которое эксплуатирует горные породы, участвующие в восстановлении запасов соляного озера. Однако расположение карьера вне территории ООПТ делает затруднительной регламентацию его деятельности в соответствии с требованием охраны природного объекта.

Несогласованная деятельность природо- и недропользователей в пределах данной системы создает условия для нарушения состояния ее динамического равновесия и активизации ряда негативных процессов, таких как нарушение процесса естественного соленакопления в озере, сокращение геологических запасов солей, загрязнение пищевых минеральных солей терригенным материалом, снижение кондиций бальнеологических илов, а также активизация карстовых процессов. Это является прямым нарушением целей создания заказника и заповедника.

Ярким примером сложности взаимодействия горного предприятия и ООПТ является история эксплуатации солепромысла оз. Баскунчак. Соляной промысел находится на территории Богдо-Баскунчакского заказника. Поэтому работу солепромысла должны регламентировать, с одной стороны, нормы и правила горного предприятия, а с другой - ООПТ. Профиль заказника - комплексный (ландшафтный), предназначен для сохранения и восстановления природных комплексов (природных ландшафтов) [3], что и отражено в Положении о создании заказника [19].

Освоение ресурсов природной системы оз. Баскунчак началось с добычи озерных солей, поэтому первые природоохранные мероприятия были направлены на защиту их качества. В конце XIX в. были сооружены защитные валы, предотвращающие засорение пласта, соблюдался строгий пропускной режим на въезде в акваторию. В 1930 г. постановлением Владимирского РИКа Нижне-Волжского края была введена санитарная зона озера, размером 2-5 км от берега озера. Лишь в 1979 г. гора Большое Богдо (147 м абс. отм.; почти 170 м возвышение над уровнем озера) приобрела статус памятника природы. В 1983 г. аналогичный статус получил участок «Зеленый Сад» Богдинской НИАГЛОС им. Орлова (в настоящее время - участок «Зеленый Сад» Богдинско-Баскунчакского заповедника). В 1985 г. памятником природы областного значения стало урочище Шарбулак (карстовое поле, прилегающее к г. Большое Богдо) [цит. по: 20].

В 1993 г. был создан Богдинско-Баскунчакский государственный природный заказник, площадь которого составила 53700 га, куда вошли ранее созданные локальные ООПТ и часть горного отвода солепромысла. В 1997 г. в соответствии постановлением Правительства Российской Федерации путем выделения части территории заказника регионального уровня организован Богдинско-Баскунчакский 
заповедник на общей площади 18478 га (состоит из двух участков: окрестностей озера Баскунчак (16476 га) и участка «Зеленый сад» (2002 га)) [цит. по: 20]. На территории сложился сложный комплекс нескольких предприятий и ООПТ, причем природоохранная функция была на одном из этапов развития территории «передана» от соляного предприятия заказнику и заповеднику.

Однако, проследив изменения в формулировках нормативных документов, регламентирующих организацию и функционирование заказника, можно сделать вывод об отсутствии реального природоохранного регулирования именно в акватории озера (т.е. на территории солепромысла). В постановлении главы администрации Астраханской области №196 от 25.11.1993 из числа ограничительных мер снят запрет только на проведение взрывных работ, традиционная формулировка запрета на «проведение геологоразведочных изысканий и разработку полезных ископаемых», осталась, пусть и немного купированной [21]. В 2008 г. было издано постановление правительства области [22], обеспечивающее статус заказника. В данном документе опять встречается запрет на геологоразведочные работы и добычу полезных ископаемых. И лишь в 2009 г. формулировка «проведение геологоразведочных изысканий и разработка полезных ископаемых» была удалена окончательно [23]. Этот пример показывает, насколько легковесны формулировки, не подтвержденные научным обоснованием реальной защиты природной системы охраняемой ООПТ. Соблюдение требования сохранения природного объекта затруднительно и на основании документов, регламентирующих деятельность горного предприятия [16].

Добыча минеральных ресурсов ориентирована на оценку потенциала лишь части природной системы (литогенной составляющей), поэтому управление всем комплексом ресурсов ценных природных объектов с позиций горного предприятия не может быть эффективным.

История развития баскунчакского солепромысла показывает, что согласование деятельности ООПТ и горного предприятия - процесс сложный и трудно реализуемый на основании действующего добычного законодательства. Причин тому много, главная из которых заключается в том, что цель создания месторождения это получение определенного ресурса и прибыли, а природоохранные мероприятия при таком подходе являются ограничителями такой деятельности, снижающими прибыль (из-за дополнительных затрат либо снижения эффективности работ). Поэтому охрана окружающей среды на месторождениях носит черты пассивного экологического менеджмента [5], целью которого является минимизация экологических издержек, а не сохранение экологического потенциала территории. Кроме того, современная нормативная база, обеспечивающая работу горного предприятия, часто не учитывает все природные процессы, необходимые для функционирования экосистемы (например, естественные ресурсы соленакопления на месторождении солей) $[9,15-18]$.

\section{Особо охраняемые природные территории и управление их ресурсами}

Рациональная эксплуатация ресурсов сложной природно-техногенной системы возможна лишь при условии рассмотрения ее как целостной системы в природных границах. Все природоохранные меры направлены на охрану отдельных частей единой природно-техногенной системы, и при этом часто отсутствует 
комплексность и обоснованность границ ООПТ. Например, для природной системы оз. Баскунчак, в которой важнейшую роль играет динамика природных вод, необходим режим, который бы в границах всей водосборной площади (и в акватории, и за ее пределами) регламентировал хозяйственную деятельность и обеспечивал равновесное состояние системы, т.е. соблюдение условий существования ООПТ и рационального использования ресурсов озера.

В ФЗ [1] отмечено, что особо охраняемые природные территории предназначены для сохранения типичных и уникальных природных ландшафтов, разнообразия животного и растительного мира, охраны объектов природного и культурного наследия. Однако, как было показано выше, существующие на территории заповедник федерального уровня и заказник регионального уровня не способны обеспечить необходимый режим хозяйствования на территории.

Одной из причин является дробность территории ООПТ (см. рисунок). Часто границы ООПТ не совпадают с естественными границами экосистемы. Это объясняется как сложностью их выделения, так и желанием местных властей минимизировать территорию, которая будет выведена из хозяйственного оборота. Таким образом, сложная форма и расположение границ ООПТ представляют собой не научно обоснованный норматив, а результат компромисса между рабочей группой, обосновывавшей создание режима территории, и местными властями.

На рисунке видно, что площадь обеих ООПТ меньше, чем водосборная площадь озера. И если солепромысел находится в пределах заказника (а акватория озера входит в его площадь), что оставляет некоторые возможности для контроля его деятельности в соответствии с режимом заказника, то гипсовый карьер (западное побережье, в водосборной площади озера) расположен вне границ ООПТ и как организация имеет полное право руководствоваться в работе нормами и правилами горного предприятия.

Вторая, по нашему мнению, причина недостатка эффективности данных ООПТ - их разобщенность, отсутствие единой стратегии и четких формулировок, отражающих функциональные особенности их существования.

Рассматриваемые ООПТ имеют статус «комплексных ландшафтных»: в Положении о государственном природном заказнике «Богдинско-Баскунчакский» [19] записано, что целью его является «...сохранение и восстановление природных комплексов озера Баскунчак, горы Большое Богдо и прилегающих к ним полупустынных ландшафтов». Тем не менее нигде не отражено значение подземных и поверхностных вод, в результате деятельности которых данные ландшафты и были созданы.

Проблема неточной формулировки целей и задач ООПТ в нашей стране в настоящее время открывает огромные просторы для махинаций и нарушений. Так, баскунчакский солепромысел не имеет сегодня законодательных ограничений своей деятельности, хотя последние 20 лет уровень добычи не превышал естественные ресурсы соленакопления озера.

\section{Предложения по совершенствованию системы ООПТ, связанных с добычей минерального сырья}

Таким образом, проблема эксплуатации природных ресурсов, связанных с ООПТ, на сегодня стоит достаточно остро. Современное законодательство, 


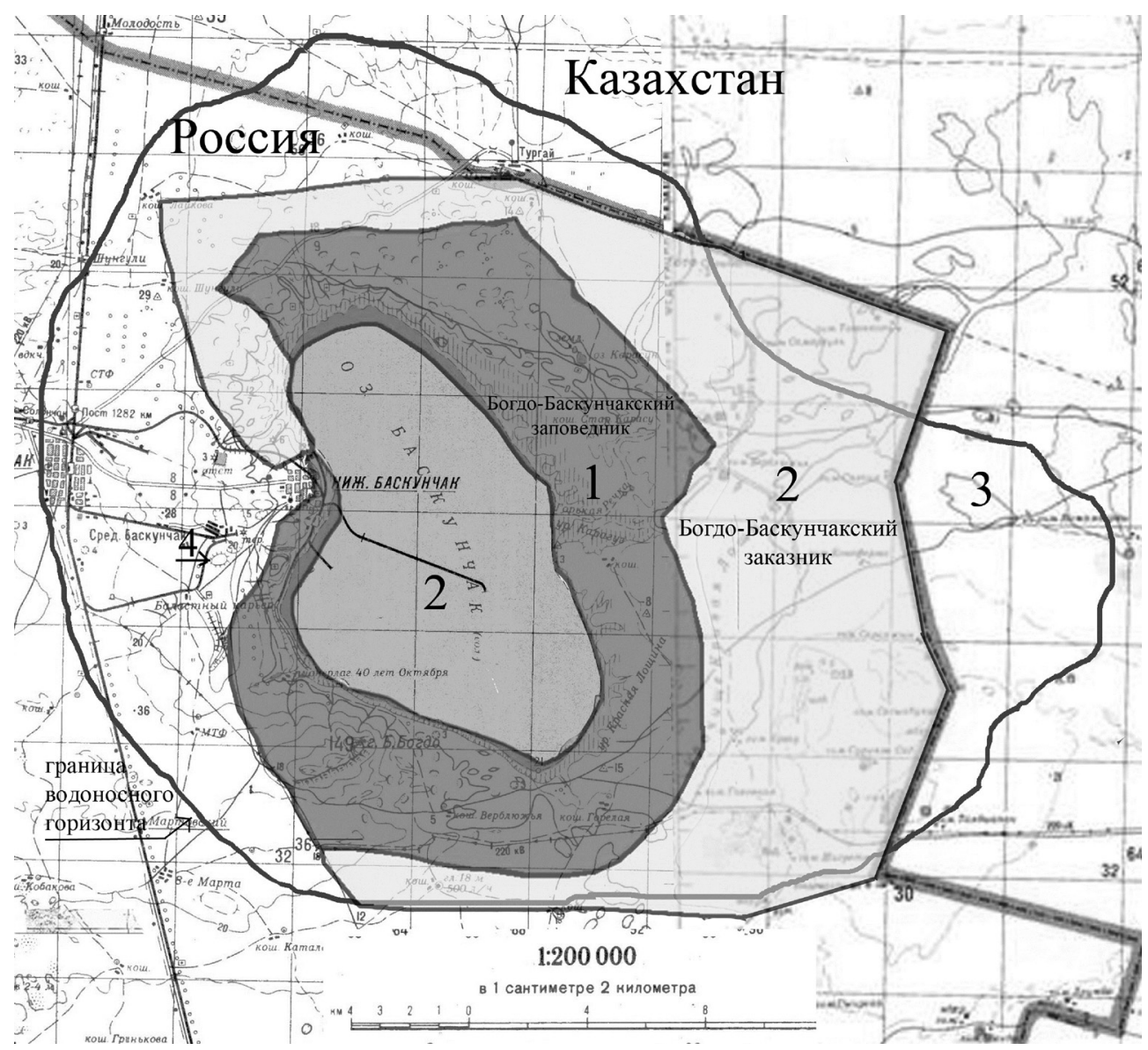

Соотношение границ существующих особо охраняемых природных территорий и природнотехногенной системы оз. Баскунчак [16]:

1 - Богдо-Баскунчакский заповедник (кластер, входящий в природно-техногенную систему оз. Баскунчак; 2 - Богдо-Баскунчакский заказник (включая акваторию озера); 3 - территория природно-техногенной системы оз. Баскунчак (акватория озера и водосборная площадь); $4-$ гипсовый карьер.

обеспечивающее функционирование ООПТ, не исключает полностью такой деятельности, однако оно не проработано в полной мере. Изменения в данной сфере необходимы не столько для организации добычи полезных ископаемых на территории охраняемых природных комплексов или вблизи их границ, сколько для прояснения механизмов взаимодействия природопользователей на уже существующих объектах.

Для добычи полезных ископаемых в ООПТ наилучшим образом подходит тип - заказник, на территории которого ограничивается любая деятельность, если она противоречит целям его создания или причиняет вред природным комплексам и их компонентам [11].

Создание традиционных заказников направленно на рациональную эксплуатацию на основе непревышения восстановительного потенциала системы, гаран- 
тирующего существование экосистемы и воспроизводство необходимого элемента в будущем [20].

Рассматриваемый воспроизводимый элемент - это чаще всего популяция какого-либо биологического вида. На системном уровне воспроизводимым элементом экосистемы может являться и ее абиотическая составляющая - минеральные ресурсы, например озерные соли оз. Баскунчак.

Обоснование границ, как было показано выше, является одним из ключевых этапов в создании ООПТ, тем не менее критерии их выделения являются дискуссионным вопросом. Современная методология оперирует понятиями «пространство, поверхность, участок биосферы», но игнорирует понятие «первичное районирование». Так, в статье [24] авторы предлагают использовать в роли первичного критерия выделения границ ООПТ геологический параметр. В качестве аргумента они приводят результаты исследования экосистем Камчатки, где границы соответствуют крайне мозаичному площадному распределению пепловых почв.

Действительно, в геологической среде существует устойчивое пространственное распределение природных ресурсов. Геологическая среда является субстратом, на котором развиваются живые организмы, и именно это распределение является главным фактором, определяющим основные характеристики будущих биологических систем.

Стоит отметить, что фактором, определяющим первичные черты любой экосистемы, являются не только геохимические особенности территории, а скорее, весь комплекс абиотических факторов. Для природно-техногенной системы оз. Баскунчак подобными факторами являются соляная тектоника и режим подземных и поверхностных вод. В работах зарубежных авторов на примере соляного оз. Галлокэнта показано, что для введения экологически ориентированного режима природопользования необходимо в качестве границ природной системы принимать именно его водосборную площадь [25]. В целом можно сказать, что именно режим природных вод является для любой территории самым быстроизменяющимся природным абиотическим фактором и наиболее подверженным антропогенному влиянию. В практике создания ООПТ так называемый бассейновый принцип выделения границ является, пожалуй, самым удобным и обоснованным.

При выделении границ особо охраняемой природной территории оз. Баскунчак необходимо использовать данные о водосборной площади озера, что обеспечит защиту системообразующего процесса восстановления запасов солей озера.

Методологию создания традиционных заказников можно применить к созданию эколого-геологических заказников - это охранный статус эколого-геологической системы, в которой, например, на основе данных о ее восстановительном потенциале эксплуатируются объекты геологической среды. Создание нового типа заказника - эколого-геологического - диктуется необходимостью обоснования границ ООПТ в соответствии с задачами охраны абиотической составляющей экосистемы, а также создания условий для ее рациональной эксплуатации.

При условии организации на территории системы оз. Баскунчак особого типа ООПТ - эколого-геологического заказника любая хозяйственная деятельность как в акватории озера, так и в пределах его водосбора будет регламентироваться условием неприкосновенности режима природных вод и непревышения естественных ресурсов соленакопления. Это позволит обеспечить, с одной стороны, 
стабильность режима восстановления запасов месторождения солей и их добычи, а с другой - безопасность проживания людей на данной территории и сохранность уникального природного объекта [26].

Поскольку минеральные ресурсы как составная часть экосистемы чаще всего не обладают свойством восстановления запасов, приведенный пример соляного прииска является узкоспециализированным. В широком смысле рациональная эксплуатация ресурсов эколого-геологического заказника должна быть ориентирована на комплексную оценку всего экологического потенциала природной системы, а возможность добычи минерального сырья определяться задачами сохранения целостности экосистемы. При таком подходе работа горного предприятия будет регламентирована нормами природоохранного законодательства и ограничена целью создания ООПТ - сохранением ценных природных объектов.

\section{Выводы}

Действующее законодательство, регулирующее работу ООПТ и месторождений минерального сырья, не позволяет обеспечить эффективное управление ресурсами сложных природных комплексов.

В настоящее время некоторые виды хозяйственной деятельности допускаются в пределах ООПТ, если это не противоречит целям их создания. Существуют даже отдельные примеры добычи полезных ископаемых в пределах заповедных зон. При этом применение положений закона [1] о невлиянии на природные системы и непротиворечии целям создания ООПТ становится достаточно эфемерным и не имеющим каких-либо научных обоснований.

По нашему мнению, проблема освоения минерального сырья ООПТ должна рассматриваться как часть задачи о рациональной эксплуатации природных ресурсов экосистем и решаться на основании комплексного подхода к оценкам всех ресурсов этих экосистем.

Создание методики управления ресурсами сложных природных систем возможно на базе нормативных документов, обеспечивающих функционирование ООПТ, путем введения в практику особого типа ООПТ - эколого-геологического заказника, в котором на основе научно обоснованных данных о границах экосистемы, взаимодействии всех компонентов и условии сохранения гомеостаза экосистемы могли бы эксплуатироваться объекты геологической среды.

Нормативы воздействия хозяйственной деятельности на экосистему должны быть ограничены пределом выносливости экосистемы по подобию добычи солей оз. Баскунчак, где они должны быть согласованы с естественными ресурсами соленакопления.

Параметры природопользования должны быть зафиксированы документально и служить основой для хозяйственной деятельности всех существующих природопользователей в пределах ООПТ на основе проектов.

\section{Литература}

1. Федеральный закон от 14 марта 1995 г. N 33-Ф3 «Об особо охраняемых природных территориях» (с изменениями и дополнениями) URL: http://base.garant.ru/10107990/\#help (дата обращения: 01.04.2016). 
2. Волков А. М. К концепции особо охраняемых природных территорий России // Заповедники и национальные парки. 1999. № 28. С. 36-48.

3. Горшков В. Г. Энергетика биосферы и устойчивость состояния окружающей среды. М.: Изд-во ВИНИТИ, 1990. 238 с. (Итоги науки и техники. Сер. теоретич. и общие вопр. геогр.; Т.7)

4. Куриленко В. В., Подлипский И. И., Осмоловская Н. Г. Эколого-геологическая и биогеохимическая оценка воздействия полигонов бытовых отходов на состояние окружающей среды // Экология и промышленность России. 2012. № 11. С.28-32.

5. Куриленко В.В. Основы управления природо- и недропользованием. Экологический менеджмент. СПб.: Изд-во СПбГУ, 2000. 206 с.

6. Подлипский И. И. Полигон бытовых отходов как объект геологического исследования // Вестн. С.-Петерб. ун-та. Сер. 7. Геология. География. 2010. Вып. 1. С. 15-31.

7. Подлипский И.И. Методика эколого-геологической оценки территории полигона бытовых отходов (пос. Пржевальское, Смоленская область) // Материалы IV международных чтений памяти Н.М. Пржевальского: «Творческое наследие Н. М. Пржевальского и современность». Смоленск: Изд-во «Манжета», 2014. С. 120-123.

8. Артемов Н. И., Середа Т. Г., Костарев С. Н., Низамутдинов О. Б. Технологии автоматизированного управления полигоном твердых бытовых отходов // Международный журнал экспериментального образования. 2010. № 11. С. 43.

9. Зайнуллин Х.Н., Абдрахманов Р.Ф., Ибатуллин У.Г., Минигазимов И. Н., Минигазимов Н.С. Обращение с отходами производства и потребления. Уфа: Министерство природных ресурсов Республики Башкортостан; Научно-исследовательский институт безопасности жизнедеятельности Республики Башкортостан, 2005. 292 с.

10. Скибин С. С. Недропользование в пределах территорий с ограниченным режимом осуществления хозяйственной деятельности: проблемы совершенствования правового регулирования (на примере особо охраняемых природных территорий) // Труды РГУ нефти и газа им. И. М. Губкина. 2013. № 2 (271). C. 116-118.

11. Давыдова М. В., Голубинская Т. Е. Проблемы недропользования на землях особо охраняемых природных территорий // Минеральные ресурсы России. 2010. № 5. С. 41-45.

12. Орлов В. П., Голубинская Т. Е., Давыдова М. В. Проблемы правового статуса особо охраняемых природных территорий // Евразийский юридический журнал. 2010. №1(20). С. 96-100.

13. Waggitt $P$. Environmental compliance requirements to be observed by active and closed-out uranium mines in northern Australia - an update // Mine Water and the Environment. 2001. Vol.20, N 4. P.178-189.

14. Deguignet M., Juffe-Bignoli D., Harrison J., MacSharry B., Burgess N. D. Kingston N. United Nations List of Protected Areas. United Nations Environment Programme, 2014. URL: http://wdpa.s3.amazonaws. com/WPC2014/2014_UN_LIST_REPORT_EN.pdf (дата обращения: 03.04.2016).

15. Зеленковский П. С., Куриленко В. В. Природно-техногенная система соляного озера Баскунчак и особенности эксплуатации ее ресурсов // Вестн. С.-Петерб. ун-та. Сер. 7. Геология. География. 2014. Вып. 4. С. 33-53.

16. Зеленковский П.С., Куриленко В.В. Проблемы регулирования хозяйственной деятельности горных предприятий в пределах сложных природно-техногенных комплексов // Петербургский юрист. 2015. № 1. С. 120-131.

17. Куриленко В.В, Зеленковский П.С. Месторождение минеральных солей озера Баскунчак: геология, особенности современного соленакопления, механизмы природо- и недропользования // Вестн. С.-Петерб. ун-та. Сер. 7. Геология. География. 2008. Вып. 3. С. 17-33.

18. Куриленко В. В. Современные бассейны эвапоритовой седиментации. СПб.: Изд-во С.-Петерб. ун-та, 1997. 255 с.

19. Распоряжение главы администрации Астраханской области от 09.03.1993 №279-P. URL: http://oopt.aari.ru/oopt/\%D0\%91\%D0\%BE\%D0\%B3\%D0\%B4\%D0\%B8\%D0\%BD\%D1\%81\%D0\%BA\%D0 \%BE-\%D0\%91\%D0\%B0\%D1\%81\%D0\%BA\%D1\%83\%D0\%BD\%D1\%87\%D0\%B0\%D0\%BA\%D1\%81\%D0 \%BA\%D0\%B8\%D0\%B9-0 (дата обращения: 14.04 2016).

20. Трегубов О.В., Солнщев В.Н., Тельнова Н.О., Глаголев С.Б. Функциональное зонирование территории государственного природного заповедника «Богдинско-Баскунчакский» // Проблемы и стратегия сохранения аридных экосистем Российской Федерации. Ахтубинск: Царицын, 2007. C. $44-48$.

21. Постановление главы администрации Астраханской области от 25.11.1993 №196, URL: http:// oopt.aari.ru/oopt/\%D0\%91\%D0\%BE\%D0\%B3\%D0\%B4\%D0\%B8\%D0\%BD\%D1\%81\%D0\%BA\%D0\%BE\%D0\%91\%D0\%B0\%D1\%81\%D0\%BA\%D1\%83\%D0\%BD\%D1\%87\%D0\%B0\%D0\%BA\%D1\%81\%D0\%BA \%D0\%B8\%D0\%B9-0 (дата обращения: 14.04 2016). 
22. Распоряжение правительства Астраханской области от 04.02.2008 №42-ПР. URL: http://oopt. aari.ru/oopt/\%D0\%91\%D0\%BE\%D0\%B3\%D0\%B4\%D0\%B8\%D0\%BD\%D1\%81\%D0\%BA\%D0\%BE-\%D0 \%91\%D0\%B0\%D1\%81\%D0\%BA\%D1\%83\%D0\%BD\%D1\%87\%D0\%B0\%D0\%BA\%D1\%81\%D0\%BA\%D0 \%B8\%D0\%B9-0 (дата обращения: 14.04 2016).

23. Постановление правительства Астраханской области от 26.02.2009 №66-П. URL: http://oopt. aari.ru/oopt/\%D0\%91\%D0\%BE\%D0\%B3\%D0\%B4\%D0\%B8\%D0\%BD\%D1\%81\%D0\%BA\%D0\%BE-\%D0 \%91\%D0\%B0\%D1\%81\%D0\%BA\%D1\%83\%D0\%BD\%D1\%87\%D0\%B0\%D0\%BA\%D1\%81\%D0\%BA\%D0 \%B8\%D0\%B9-0 (дата обращения: 14.042016 ).

24. Яроикий Г.П., Тарасов А. В. Геологические критерии при определении границ особо охраняемых природных территорий // Геоэкология. 2008. № 2. С. 124-129.

25. Comín F. A., Cabrera M., Rodó X. Saline lakes: integrating ecology into their management future // Hydrobiologia. 1999. 395/396. P. 241-251.

26. Зеленковский П.С. Эксплуатация природных ресурсов особо охраняемых территорий на примере оз. Баскунчак // Материалы IV международных чтений памяти Н.М.Пржевальского: «Творческое наследие Н. М. Пржевальского и современность». Смоленск: Изд-во «Манжета», 2014. C. $167-173$.

Для цитирования: Зеленковский П. С., Подлипский И. И., Хохряков В. Р. Проблемы регулирования деятельности хозяйствующих субъектов при разработке месторождений полезных ископаемых в границах особо охраняемых природных территорий // Вестник СПбГУ. Серия 7. Геология. География. 2016. Вып. 3. С. 60-73. DOI: 10.21638/11701/spbu07.2016.305

\section{References}

1. Federal'nyi zakon ot 14 marta $1995 \mathrm{~g} . \mathrm{N} 33-\mathrm{FZ}$ «Ob osobo okhraniaemykh prirodnykh territoriiakh» (s izmeneniiami i dopolneniiami) [Federal Law № 33 "On Specially Protected Natural Areas" (as amended). March 14, 1995]. Available at: http://base.garant.ru/10107990/\#help (accessed 01.04.2016). (In Russian)

2. Volkov A. M. K kontseptsii osobo okhraniaemykh prirodnykh territorii Rossii [On the concept of protected areas in Russia]. Zapovedniki i natsional'nye parki [Reserves and National Parks], 1999, no. 28, pp. 36-48. (In Russian)

3. Gorshkov V. G. Energetika biosfery i ustoichivost' sostoianiia okruzhaiushchei sredy [Energy of the biosphere and sustainability of the environment]. Moscow, VINITI Publ., 1990. 238 p. (Itogi nauki i tekhniki. Ser. teoretich. i obshchie vopr. geogr.; T. 7 [Results of Science and Technology. Series. Theoretical and general problems of geography; vol.7])

4. Kurilenko V. V., Podlipskii I. I., Osmolovskaia N. G. Ekologo-geologicheskaia i biogeokhimicheskaia otsenka vozdeistviia poligonov bytovykh otkhodov na sostoianie okruzhaiushchei sredy [Ecological and geological and biogeochemical impact assessment of landfill waste on the environment]. Ekologiia i promyshlennost' Rossii [Ecology and Industry of Russia], 2012, no. 11, pp. 28-32. (In Russian)

5. Kurilenko V. V. Osnovy upravleniia prirodo- i nedropol'zovaniem [Principles of Management of exploitation of mineral resources]. Ekologicheskii menedzhment [Environmental management]. St. Petersburg, St. Petersburg University Press, 2000. 206 p. (In Russian)

6. Podlipskii I. I. Poligon bytovykh otkhodov kak obekt geologicheskogo issledovaniia [Landfill waste as an object of philological research]. Vestnik of Saint Petersburg University. Ser. 7. Geology. Geography, 2010, issue 1, pp. 15-31. (In Russian)

7. Podlipskii I.I. Metodika ekologo-geologicheskoi otsenki territorii poligona bytovykh otkhodov (pos. Przheval'skoe, Smolenskaia oblast') [Methodology of ecological and geological evaluation of the landfill waste (pos. Przhevalskoye, Smolensk region)]. Materialy IV mezhdunarodnykh chtenii pamiati N. M. Przheval'skogo: "Tvorcheskoe nasledie N. M. Przheval'skogo i sovremennost'» [Materials of IV international readings in memory of N. M. Przewalskii: "The creative heritage of N. M. Przewalskii and modernity"]. Smolensk, Publishing house "Manjeta", 2014, pp. 120-123. (In Russian)

8. Artemov N. I., Sereda T. G., Kostarev S. N., Nizamutdinov O. B. Tekhnologii avtomatizirovannogo upravleniia poligonom tverdykh bytovykh otkhodov [Technology of automated management of solid waste]. Mezhdunarodnyi zhurnal eksperimental'nogo obrazovaniia [International Journal of Experimental Education], 2010, no. 11, pp. 43. (In Russian)

9. Zainullin Kh. N., Abdrakhmanov R. F., Ibatullin U. G., Minigazimov I. N., Minigazimov N. S. Obrashchenie s otkhodami proizvodstva i potrebleniia [Waste production and consumption]. Ministerstvo prirodnykh resursov Respubliki Bashkortostan; Nauchno-issledovatel'skii institut bezopasnosti zhiznedeiatel'nosti Re- 
spubliki Bashkortostan [Ministry of Natural Resources of the Republic of Bashkortostan; Research Institute of Life Safety RB]. Ufa, 2005. 292 p. (In Russian)

10. Skibin S.S. Nedropol'zovanie v predelakh territorii s ogranichennym rezhimom osushchestvleniia khoziaistvennoi deiatel'nosti: problemy sovershenstvovaniia pravovogo regulirovaniia (na primere osobo okhraniaemykh prirodnykh territorii) [Exploitation of mineral resources within the territories of the limited regime of economic activities: Improving the legal regulation (for example, specially protected areas)]. Trudy RGU nefti i gaza im. I. M. Gubkina [Proceedings of the I. M. Gubkin Russian State University of Oil and Gas], 2013, no. 2 (271), pp. 116-118. (In Russian)

11. Davydova M.V., Golubinskaia T.E. Problemy nedropol'zovaniia na zemliakh osobo okhraniaemykh prirodnykh territorii [Problems of exploitation of mineral resources on the lands of protected areas]. Mineral'nye resursy Rossii [Mineral resources of Russia], 2010, no. 5, p. 41-45. (In Russian)

12. Orlov V.P., Golubinskaia T.E., Davydova M. V. Problemy pravovogo statusa osobo okhraniaemykh prirodnykh territorii [Problems of the legal status of protected areas]. Evraziiskii iuridicheskii zhurnal [Eurasian Law zhurnal], 2010, vol. 1 (20), pp.96-100. (In Russian)

13. Waggitt P. Environmental compliance requirements to be observed by active and closed-out uranium mines in northern Australia - an update. Mine Water and the Environment, 2001, vol.20, no. 4, pp. 178-189.

14. Deguignet M., Juffe-Bignoli D., Harrison J., MacSharry B., Burgess N.D., Kingston N. United Nations List of Protected Areas. United Nations Environment Programme, 2014. Available at: http://wdpa. s3.amazonaws.com/WPC2014/2014_UN_LIST_REPORT_EN.pdf (accessed: 03.04.2016).

15. Zelenkovskii P.S., Kurilenko V.V. Prirodno-tekhnogennaia sistema solianogo ozera Baskunchak i osobennosti ekspluatatsii ee resursov [Natural and technogenic system of salt lake Baskunchak and operating features of its resources]. Vestnik of Saint Petersburg University. Series 7. Geology. Geography, 2014, issue 4, pp. 33-53. (In Russian)

16. Zelenkovskii P.S., Kurilenko V.V. Problemy regulirovaniia khoziaistvennoi deiatel'nosti gornykh predpriiatii v predelakh slozhnykh prirodno-tekhnogennykh kompleksov [Problems of regulation of economic activities of mining companies within the complex natural and man-made complexes]. Peterburgskii iurist [The St. Petersburg lawyer], 2015, no. 1, pp. 120-131. (In Russian)

17. Kurilenko V.V, Zelenkovskii P.S. Mestorozhdenie mineral'nykh solei ozera Baskunchak: geologiia, osobennosti sovremennogo solenakopleniia, mekhanizmy prirodo- i nedropol'zovaniia [The deposit of Baskunchak Lake mineral salts: geology, features of modern salt accumulation, exploitation mechanisms]. Vestnik of Saint Petersburg University. Series 7. Geology. Geography, 2008, issue 3, pp. 17-33. (In Russian)

18. Kurilenko V.V. Sovremennye basseiny evaporitovoi sedimentatsii [Modern evaporite sedimentation basins]. St. Petersburg, St. Petersburg University Press, 1997, 255 p. (In Russian)

19. Rasporyazhenie glavy administracii Astrahanskoj oblasti ot 09.03.1993 №279-R. Available at: http:// oopt.aari.ru/oopt/\%D0\%91\%D0\%BE\%D0\%B3\%D0\%B4\%D0\%B8\%D0\%BD\%D1\%81\%D0\%BA\%D0\%BE\%D0\%91\%D0\%B0\%D1\%81\%D0\%BA\%D1\%83\%D0\%BD\%D1\%87\%D0\%B0\%D0\%BA\%D1\%81\%D0\%BA \%D0\%B8\%D0\%B9-0 (accessed: 14.042016 ).

20. Tregubov O. V., Solntsev V.N., Tel'nova N.O., Glagolev S. B. Funktsional'noe zonirovanie territorii gosudarstvennogo prirodnogo zapovednika "Bogdinsko-Baskunchakskii» [Functional zoning of the State Natural Reserve "Bogdinsko-Baskunchaksky"]. Problemy i strategiia sokhraneniia aridnykh ekosistem Rossiiskoi Federatsii [Problems and strategy for the conservation of arid ecosystems of the Russian Federation]. Akhtubinsk, Tsaritsyn Publ., 2007, pp. 44-48. (In Russian)

21. Postanovlenie glavy administracii Astrahanskoj oblasti ot 25.11.1993 №196. Available at: http://oopt. aari.ru/oopt/\%D0\%91\%D0\%BE\%D0\%B3\%D0\%B4\%D0\%B8\%D0\%BD\%D1\%81\%D0\%BA\%D0\%BE-\%D0 \%91\%D0\%B0\%D1\%81\%D0\%BA\%D1\%83\%D0\%BD\%D1\%87\%D0\%B0\%D0\%BA\%D1\%81\%D0\%BA\%D0 \%B8\%D0\%B9-0 (accessed: 14.04 2016).

22. Rasporyazhenie pravitel'stva Astrahanskoj oblasti ot 04.02.2008 №42-PR. Available at: http://oopt. aari.ru/oopt/\%D0\%91\%D0\%BE\%D0\%B3\%D0\%B4\%D0\%B8\%D0\%BD\%D1\%81\%D0\%BA\%D0\%BE-\%D0 \%91\%D0\%B0\%D1\%81\%D0\%BA\%D1\%83\%D0\%BD\%D1\%87\%D0\%B0\%D0\%BA\%D1\%81\%D0\%BA\%D0 \%B8\%D0\%B9-0 (accessed: 14.04 2016).

23. Postanovlenie pravitel'stva Astrahanskoj oblasti ot 26.02.2009 №66-P. Available at: http://oopt.aari. ru/oopt/\%D0\%91\%D0\%BE\%D0\%B3\%D0\%B4\%D0\%B8\%D0\%BD\%D1\%81\%D0\%BA\%D0\%BE-\%D0\%91 \%D0\%B0\%D1\%81\%D0\%BA\%D1\%83\%D0\%BD\%D1\%87\%D0\%B0\%D0\%BA\%D1\%81\%D0\%BA\%D0\%B8 \%D0\%B9-0 (accessed: 14.04 2016).

24. Iarotskii G.P., Tarasov A.V. Geologicheskie kriterii pri opredelenii granits osobo okhraniaemykh prirodnykh territorii [Geological criteria for determining the boundaries of protected areas]. Geoekologiia [Geoecology], 2008, no. 2, pp. 124-129. (In Russian) 
25. Comín F. A., Cabrera M., Rodó X. Saline lakes: integrating ecology into their management future [Saline lakes: integrating ecology into their management future]. Hydrobiologia [Hydrobiology], 1999, 395/396, pp. 241-251. (In Russian)

26. Zelenkovskii P.S. Ekspluatatsiia prirodnykh resursov osobo okhraniaemykh territori na primere oz. Baskunchak [The exploitation of natural resources of the protected areas on the example of lake Baskunchak]. Materialy IV mezhdunarodnykh chtenii pamiati N. M. Przheval'skogo: "Tvorcheskoe nasledie N. M. Przheval'skogo i sovremennost'» [Materials of IV international readings in memory N. M. Przewalskii: "The creative heritage of N. M. Przewalskii and modernity"]. Smolensk, Publishing house "Manjeta", 2014, pp. 167-173. (In Russian)

For citation: Zelenkovskii P. S., Podlipsky I. I., Khokhryakov V.R. Problems of regulation of activity of economic entities in the development of mineral deposits within the boundaries of protected areas. Vestnik SPbSU. Series 7. Geology. Geography, 2016, issue 3, pp. 60-74. DOI: 10.21638/11701/spbu07.2016.305

Статья поступила в редакцию 30 мая 2016 г.

Контактная информация:

Зеленковский Павел Сергеевич - кандидат геолого-минералогических наук, доцент; p.zelenkovskii@spbu.ru

Подлипский Иван Иванович - кандидат геолого-минералогических наук;

i.podlipskiy@spbu.ru

Хохряков Владимир Рабаэльевич - кандидат биологических наук; khokhryakovy@yandex.ru

Zelenkovskii Pavel S. — PhD; p.zelenkovskii@spbu.ru

PodlipskyIvan I. - PhD; i.podlipskiy@spbu.ru

Khokhryakov Vladimir R. — PhD; khokhryakovy@yandex.ru 